\title{
Ethyl $p$-methoxycinnamate from Kaempferia galanga inhibits angiogenesis through tyrosine kinase
}

\author{
Juni Ekowati*, Suko Hardjono*, and Iwan Sahrial Hamid**
}

\begin{abstract}
BACKGROUND

Many tumors express on their receptor tyrosine kinases vascular endothelial growth factor activity associated with angiogenesis. Inhibition of angiogenesis through reduction of tyrosine kinase activity is a promising strategy for cancer therapy. The present study aimed to determine the mechanism and potency of ethyl $p$-methoxycinnamate (EPMC) isolated from Kaempferia galanga as angiogenesis inhibitor.
\end{abstract}

\section{METHODS}

A laboratory experimental study was conducted using chorio-allantoic membranes (CAMs) of nine-day old chicken eggs induced by $60 \mathrm{ng}$ basic fibroblast growth factor (bFGF). Ethyl $p$-methoxycinnamate (EPMC) potency was determined at dosages of 30,60, 90 and $120 \mu \mathrm{g}$ and compared with celecoxib $60 \mu \mathrm{g}$ as reference drug and one negative bFGF-induced control group. Neovascularization and endothelial cell count in CAM blood vessels were evaluated. To predict the antiangiogenic mechanism of EPMC, a docking study was performed with the Molegro Virtual Docker program on tyrosine kinase as receptor (PDB 1XKK).

\section{RESULTS}

Angiogenesis stimulation by bFGF was prevented significantly $(\mathrm{p}<0.05)$ by EPMC at dosages of 30, 60, 90 and $120 \mu \mathrm{g}$ and this activity was dose dependent. Molecular docking showed interaction between EPMC functional groups and tyrosine kinase amino acids at Met766, Met793, Thr854, Thr790, Gln791 and Ala743. There was an association between EPMC antiangiogenic activity and docking study results.

\section{CONCLUSIONS}

Ethyl $p$-methoxycinnamate is a potential new angiogenesis inhibitor through interaction with tyrosine kinase. EPMC could be a promising therapeutic agent for treatment of angiogenesis-related diseases.

Keywords: Ethyl p-methoxycinnamate, chorio-allantoic membrane, angiogenesis, tyrosine kinase
*Department of Pharmaceutical Chemistry, Faculty of Pharmacy, Airlangga University,

Surabaya

**Department of Molecular Pharmacology,

Faculty of Veterinary Medicine, Airlangga University,

Surabaya

Correspondence

Dr. Juni Ekowati, Apt., M.Si

Department of Pharmaceutical

Chemistry,

Faculty of Pharmacy,

Airlangga University

Kampus B Unair

Jl. Dharmawangsa Dalam

Surabaya 60286

Email: j_ekowati@yahoo.com

Univ Med 2015;34:43-51

DOI: 10.18051/UnivMed.2016.v35.43-51 pISSN: 1907-3062 / eISSN: 2407-2230

This open access article is distributed under a Creative Commons AttributionNon Commercial-Share Alike 4.0 International License 


\section{Etil p-metoksisinamat dari Kaempferia galanga menghambat angiogenesis melalui interaksi dengan tirosin kinase}

\section{ABSTRAK}

\section{LATAR BELAKANG}

Banyak tumor menunjukkan pada reseptor tirosin kinasenya ekspresi vascular endothelial growth factor yang berhubungan dengan angiogenesis. Hambatan angiogenesis melalui pengurangan aktivitas tirosin kinase adalah strategi yang menjanjikan untuk terapi kanker. Penelitian ini bertujuan untuk menentukan mekanisme dan potensi etil p-metoksisinamat

(EPMC) sebagai penghambat angiogenesis.

\section{METODE}

Sebuah studi eksperimental laboratorium dilakukan menggunakan chorio-allantoic membrane (CAM) telur ayam tertunas berumur sembilan hari, yang diinduksi dengan basic fibroblast growth factor (bFGF) 60ng. Potensi EPMC diteliti pada dosis 30, 60, 90 dan $120 \mu \mathrm{g}$; dibandingkan dengan celecoxib $60 \mu \mathrm{g}$ sebagai obat referensi dan satu grup tanpa perlakuan. Neovaskularisasi dan sel endotel pembuluh darah baru dari CAM dihitung dan dievaluasi. Untuk prediksi mekanisme antiangiogenesis EPMC, dilakukan studi doking pada reseptor tirosin kinase (PDB 1XKK) menggunakan program Molegro Virtual Docker v.5.5

\section{HASIL}

Stimulasi angiogenesis oleh bFGF pada CAM dihambat secara signifikan (p<0.05) oleh EPMC pada dosis 30, 60, 90 and $120 \mu \mathrm{g}$ dan bersifat dose dependent. Celecoxib dan EPMC tersebut menyebabkan terjadinya lisis sel endotel dari CAM. Studi doking menunjukkan adanya interaksi antara gugus fungsi pada EPMC dengan residu asam amino tirosin kinase pada Met766, Met793, Thr854, Thr790, Gln791 dan Ala743. Studi doking dan aktifitas antiangiogenesis EPMC tersebut menunjukkan hasil yang berhubungan.

\section{KESIMPULAN}

Etil p-metoksisinamat merupakan senyawa yang berpotensi sebagai angiogenesis inhibitor melalui hambatan pada tirosin kinase.

Kata kunci : Etil p-metoksinamat, korio allantois membran, angiogenesis, tirosin kinase

\section{INTRODUCTION}

Tyrosine kinase receptors of many tumors express vascular endothelial growth factor (VEGF) activity connected with angiogenesis. ${ }^{(1)}$ In the last decade, angiogenesis has been explored in depth as an interesting cancer therapeutic target, since angiogenesis is an important step in tumor growth and cancer metastasis. $^{(2,3)}$

Drug resistance, increased tumor progression, and signs of drug toxicity such as bleeding, fatigue, hypertension and gastrointestinal perforation are the main clinical problems that occur in patients treated with angiogenesis inhibitors. ${ }^{(1)}$ Thus, the use of natural herbal alternative agents to constrain angiogenesis is quite crucial in cancer treatment. Ethyl $p$-methoxycinnamate (EPMC), a major constituent of Kaempferia galanga Linn. (local name: kencur, Fam. Zingiberaceae) has been used as sunscreen, ${ }^{(4)}$ analgesic ${ }^{(5)}$ and antiinflammatory. ${ }^{(6,7)}$ agent, as cyclooxygenase- 2 (COX-2) inhibitor, and to treat fibrosarcoma in mice. ${ }^{(8)}$ It is has been established that $\mathrm{PGE}_{2}$ production in preclinical breast and colon cancer 
models is strongly influenced by COX-2 expression. COX-2 inhibition augments VEGF pathway blockade to destroy angiogenesis and tumor growth, avoid metastasis, and increase overall patient survival. ${ }^{(9-11)}$

It has also been reported that EPMC exerts anti-angiogenic activity in zebrafish ${ }^{(12)}$ and can block endothelial function. ${ }^{(6)}$ One method for the study of anti-angiogenic activity is by means of the chorio-allantoic membrane (CAM) model. The CAM is an extra-embryonic membrane formed on day 4 of incubation by fusion of the chorion and the allantois. The CAM contains extracellular matrix proteins that mimic the physiological cell environment and vascularization of cancers. Use of CAM has the advantages of easy accessibility and low cost, and is less time consuming. ${ }^{(13,14)}$ The present study was done because there have been no reports of the potency of EPMC to inhibit angiogenesis in the CAM model.

He et al. ${ }^{(12)}$ reported that EPMC influences multiple molecular targets of angiogenesis, therefore we evaluated the possibility of EPMCmediated tyrosine kinase inhibition by performing a virtual molecular docking study using the Molegro Virtual Docker program (PDB 1XKK). The objectives of our study were to determine the antiangiogenic potency of EPMC and to predict whether the mechanism of action of this compound is related to its interaction with tyrosine kinase.

\section{METHODS}

\section{Research design}

This laboratory experimental study was conducted from May 2014 until September 2014. The research was performed in three steps, i.e. molecular docking study, isolation of EPMC from Kaempferia galanga and antiangiogenic assay using the CAM model.

\section{Docking study}

Molecular docking studies of EPMC, celecoxib and the reference ligand FMM_91[A] (lapatinib tosylate) into the three-dimensional tyrosine kinase structure were carried out using Molegro Virtual Docker (MVD) software version 5.5. The receptor tyrosine kinase structure was obtained from the Protein Data Bank (PDB 1XKK). Ligand preparation was done using ChemBio Ultra software version 10.0.; the geometry was optimized by the MMFF 94 method and saved in Sybyl Mol2 format. All ligands were placed into the binding site of 1XKK (cavity-1) by alignment with the reference ligand FMM_91[A]) and 10 independent runs were performed. ${ }^{(15,16)}$ The binding affinity between ligand and enzyme (docking score) was predicted using rerank scores. Higher negative scores $(\mathrm{kcal} / \mathrm{mol})$ indicate stronger ligandenzyme binding, with the ligand filling the same pocket in the enzyme as in FMM_91[A] docking. Validation of the docking study was carried out by redocking FMM_91[A] into cavity-1 of 1XKK. The best docking results can be observed visually by comparing the structure of the docked molecules with the crystal structure of FMM_91[A] into the binding site.

\section{Isolation of ethyl-p-methoxycinnamate from Kaempferia galanga}

Kaempferia galanga Linn. was collected and determined by the botanist at Materia Medica Botanical Garden Park at Batu (near Malang), Indonesia, in August 2013. EPMC was isolated from Kaempferia galanga Linn. by extraction of the dried powder of the rhizomes $(1 \mathrm{~kg})$ with petroleum ether until the filtrate was nearly transparent. ${ }^{(6)}$ The extract was filtered and concentrated in a Rotavapor Model Laborota 4000 vacuum evaporator (Heidolph Instruments, Germany) at $25^{\circ} \mathrm{C}$, and then kept in the freezer. The extract was carefully washed with $n$-hexane, and the $n$-hexane supernatant was then decanted. This process was repeated until the solvent was almost transparent. ${ }^{(6)}$ The residue that remained after washings consisted of pale yellow, needlelike crystals, which were recrystallized with ethanol 70\%, yielding white pure EPMC crystals (10.2 g), with a sharp melting point of $49^{\circ} \mathrm{C}$, as 
observed using a Fisher-John melting point apparatus. The chemical structure was characterized spectroscopically using a Jasco Fourier transform infra red (FT-IR) 5300 spectrophotometer and a nuclear magnetic resonance (NMR) Hitachi R-1900 spectrometer, confirming its identity as EPMC.

The IR and NMR spectroscopy results were as follows: IR (KBr) 3007, 2980, 2935, 1705, $1630,1602,1253,1209,829 \mathrm{~cm}^{-1}$; [ ${ }^{1} \mathrm{H}$ NMR $\left(400 \mathrm{MHz}, \mathrm{CDCl}_{3}\right)$ ä: $3.82\left(3 \mathrm{H}, \mathrm{s}, 1 \mathrm{xOCH}_{3}\right)$; $6.96(1 \mathrm{H}, \mathrm{d}, J=15.9 \mathrm{~Hz}, 1 \mathrm{xCH}$ alkene $) ; 6.88$ $(2 \mathrm{H}, \mathrm{d}, J=8.8 \mathrm{~Hz}, 2 \mathrm{xCH}$ benzylic $) ; 6.96(1 \mathrm{H}$, $\mathrm{d}, J=15.9 \mathrm{~Hz}, 1 \mathrm{xCH}$ alkene $) ; 7.46(2 \mathrm{H}, \mathrm{d}, J=$ $8.8 \mathrm{~Hz}, 2 \mathrm{xCH}$ benzylic); $4.24\left(2 \mathrm{H}, \mathrm{q}, 1 \mathrm{xCH}_{2}\right)$; $1.32\left(3 \mathrm{H}, \mathrm{t}, J=7.2 \mathrm{~Hz}, 1 \times \mathrm{xCH}_{3}\right) \cdot\left[{ }^{13} \mathrm{C}\left({ }^{1} \mathrm{H}\right) \mathrm{NMR}\right.$ $\left(400 \mathrm{MHz}, \mathrm{CDCl}_{3}\right)$ ä : $14.4\left(\mathrm{CH}_{3}\right), 55.4\left(\mathrm{OCH}_{3}\right)$, $60.4\left(\mathrm{CH}_{2}\right), 114.4$ (benzylic $\left.\mathrm{CH} 2\right), 115.8(\mathrm{CH}$ alkene), 129.8(Ar-C), 144.3 (CH alkene), 161.2 (Ar-C), 167.4 (carbonyl C)].

\section{Antiangiogenic activity of EPMC}

Twenty-four nine-day old chicken eggs were obtained from PUSVETMA Surabaya, and incubated at $37^{\circ} \mathrm{C}$ and $60-70 \%$ humidity. After $1 \mathrm{~d}$ of incubation, a $1 \mathrm{~cm}^{2}$ window was opened at the top of the egg and the air was aspirated from the air chamber with a rubber ball until the CAM came in contact with the eggshell membrane. On all CAMs of the experimental groups, induction of new blood vessels was performed with bFGF $60 \mathrm{ng}$ dissolved in $60 \mathrm{~mL}$ of stock rh bFGF at a concentration of $1 \mathrm{ng} / \mathrm{mL}$ in a laminar air flow hood under aseptic conditions. The eggs were distributed in six groups; four groups were treated with EPMC at dosages of $30,60,90$ and $120 \mu \mathrm{g}$; one group was treated with celecoxib $60 \mu \mathrm{g}$ as the positive control group, and one group was left without any treatment except bFGF blood vessel induction as the negative control group. To verify EPMC antiangiogenic activity, a CAM assay was accomplished with certain modifications as described before. ${ }^{(13,17)}$ Sterile 5-mm diameter Whatman qualitative filter-paper disks containing bFGF alone, or supplemented with
EPMC (at dosages of 30, 60, 90 and $120 \mu \mathrm{g}$ ) or with celecoxib $60 \mu \mathrm{g}$, were implanted onto the CAM of each embryo. The window was resealed with adhesive tape and the eggs were returned to the incubator until day 11 of chick embryo development. After that, the upper eggshell was removed and neovascularization as positive parameter was characterized by capillary branching of the main blood vessels onto the bFGF-containing paper disks. The capillaries attached at the edges and on the upper and lower surfaces of the paper disks. The neovascularization parameter was considered to be negative if no capillary blood vessel formation occurred on the edges and upper and lower surfaces of the disk. Those capillaries within 2,5 $\mathrm{mm}$ around the filter paper disk were observed and photographed. Neovascularization around the disk was counted by determining the number of capillary branching of the main CAM blood vessels onto the disk. In addition to macroscopic observation as mentioned above, we also carried out microscopic observations in the following way: the CAM was removed from the shell, $10 \%$ formalin was added as preservative, and the CAM was then prepared into histological slides and stained with Hematoxylin and Eosin (HE). ${ }^{(13,17,18)}$ Endothelial cell formation in the neovascular capillaries was observed in CAM cross-sections using an inverted Nikon H600L phase contrast microscope. Endothelial cell counts were determined in five visual fields of each slide at 400x magnification and compared with positive and negative controls for subsequent analysis.

\section{Statistical analysis}

Significant differences between the treatment and control group were assessed by one-way analysis of variance (ANOVA), supported by LSD test. Differences were considered significant at $\mathrm{p}<0.05$.

\section{Ethical clearance}

This assay was approved by the Ethical Commision of Airlangga University. 

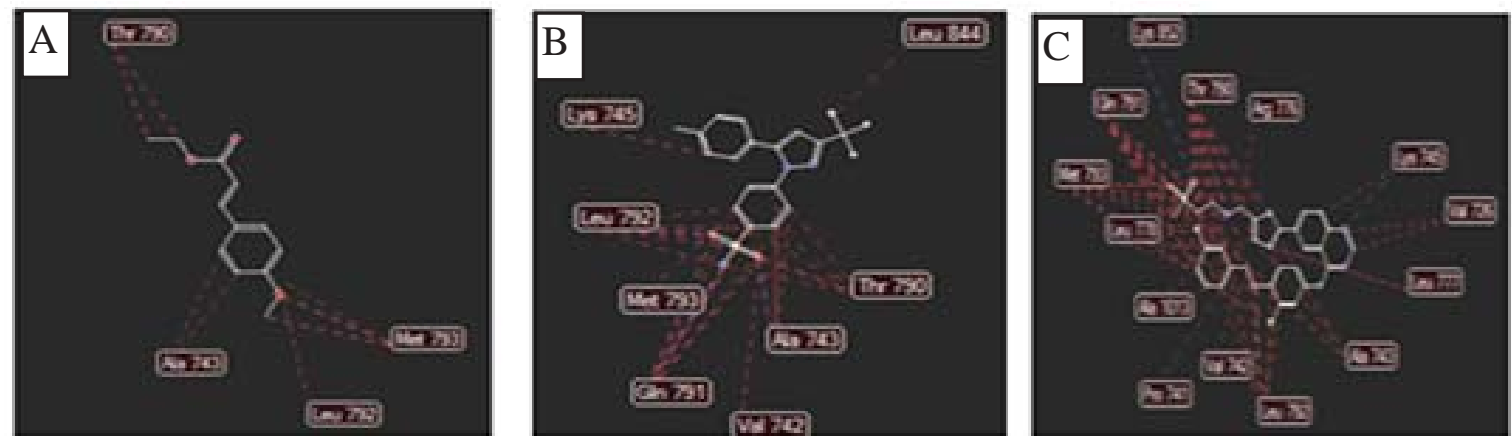

Figure 1. Interaction of EPMC (A), celecoxib (B), and FMM_91 [A] (C) with amino acids residue of tyrosine kinase (PDB 1XKK)

\section{RESULTS}

The results of the molecular docking study (rerank scores) were $-87.84 \mathrm{kcal} / \mathrm{mol}$ (EPMC); $-92.3184 \mathrm{kcal} / \mathrm{mol}$ (celecoxib); $-143.23 \mathrm{kcal} / \mathrm{mol}$ (FMM_91[A]), in which the best dock of EPMC, celecoxib and FMM_91[A] into tyrosine kinase was conducted in cavity-1 of the receptor. Their interaction with tyrosine kinase (cavity-1 PDB $1 \mathrm{XKK}$ ) is shown in Figure 1. Lapatinip tosylate displayed hydrogen bonding interaction between the following pairs: oxygen of ether moiety vs. Leu792; nitrogen of amino moiety and oxygen of furan ring vs Thr790; nitrogen of quinazoline ring vs. Lys745; oxygen of sulphonyl moiety vs. Gln791 and Lys852. Celecoxib presented hydrogen bonding interaction of the sulphonamide moiety with Ala743, Gln791 and Leu792. However, it showed steric and hydrophobic interaction of the trifluoromethyl moiety with Leu844, of the aromatic ring with Lys745, Ala743, and Met793, and of the sulphonamide moiety with Val742, Gln791 and Leu792 amino acid residues. EPMC showed hydrogen bonding interaction of the oxygen moiety with Met793, and steric and hydrophobic interaction of the Met766, Thr854, Thr790, Gln791 and Ala743 of tyrosine kinase. It was concluded that functional groups of EPMC can interact with some tyrosine kinase amino acids, similar to those of celecoxib and lapatinib tosylate.

Treatment of CAM bFGF-induced neovascularization with celecoxib $60 \mu \mathrm{g}$ caused endothelial cell lysis of the blood vessels and reduced CAM neovascularization. Celecoxib suppressed CAM neovascularization by $83.4 \pm$ $5.3 \%$ and growth of endothelial cells in capillary branches by $76.8 \pm 2.2 \%$. The potency of EPMC as angiogenic inhibitor was dose-dependent. At doses of 30, 60, 90 and $120 \mu \mathrm{g}$, EPMC inhibited neovascularization by $50.3 \pm 4.5 \%, 67.6 \pm 4.9 \%$, $77.6 \pm 6.3 \%$, and $81.9 \pm 3.2 \%(\mathrm{p}<0.05)$ respectively. At the doses of 30,60, 90 and 120 $\mu \mathrm{g}$, EPMC inhibited endothelial cell counts in capillary branches of CAM by $50.9 \pm 4.1 \%, 55.4$ $\pm 2.9 \%, 66.1 \pm 4.7 \%$, and $73.2 \pm 4.5 \%$, respectively $(\mathrm{p}<0.05)($ Table 1$)$.

Table 1. Antiangiogenesis activity of EPMC by treatment group using CAM model

\begin{tabular}{|c|c|c|c|}
\hline Treatment & $\begin{array}{c}\% \text { inhibition of } \\
\text { ne ovasc ularization }\end{array}$ & $\begin{array}{l}\% \text { inhbition of } \\
\text { endothe lial cels }\end{array}$ & $\mathbf{p}$ \\
\hline Celecoxib $60 \mu \mathrm{g}$ & $83.4 \pm 5.3$ & $76.8 \pm 2.2$ & 0.008 \\
\hline EPMS $120 \mu \mathrm{g}$ & $81.9 \pm 3.2$ & $73.2 \pm 4.5$ & 0.021 \\
\hline EPMS $90 \mu \mathrm{g}$ & $77.6 \pm 6.3$ & $66.1 \pm 4.7$ & 0.009 \\
\hline EPMS $60 \mu \mathrm{g}$ & $67.6 \pm 4.9$ & $55.4 \pm 2.9$ & 0.014 \\
\hline EPMS $30 \mu \mathrm{g}$ & $50.3 \pm 4.5$ & $50.9 \pm 4.1$ & 0.037 \\
\hline
\end{tabular}

All values are represented as the mean $\pm \mathrm{SD}(\mathrm{n}=4)$ and indicate significant differences compared with the control-untreated group at $\mathrm{p}<0.05$ 

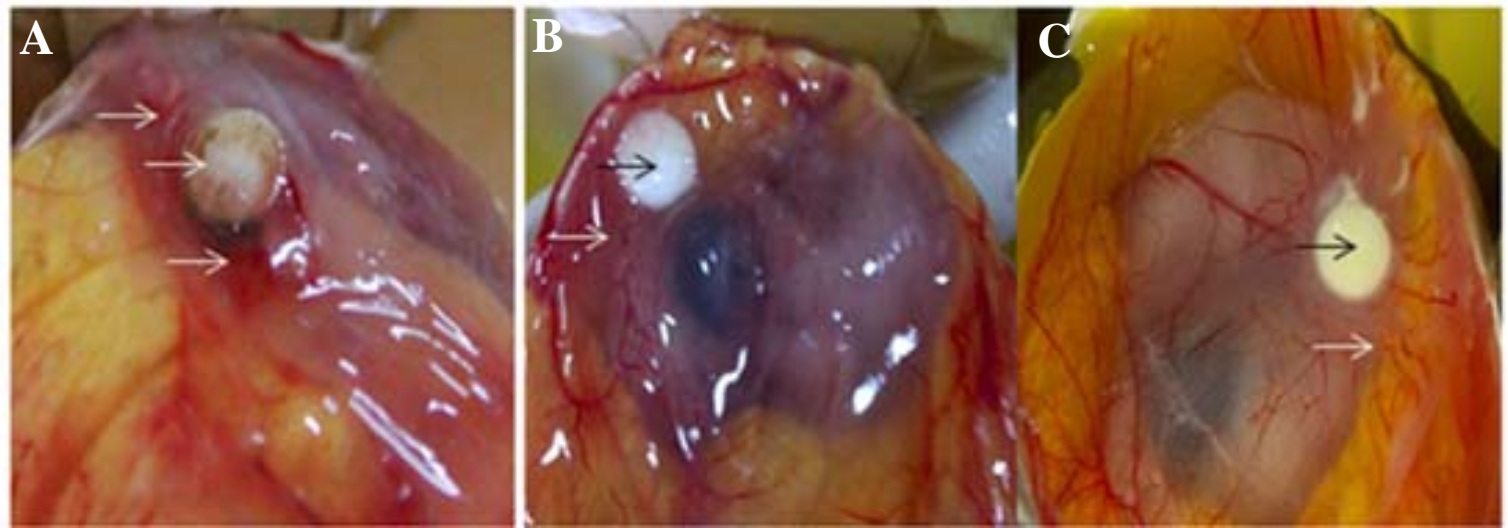

Figure 2. (A) Capillary of neovascularization of CAM induced by bFGF 60ng (white arrow), some of capillary blood vessels moving into the disk implanted on CAM; (B) Capillary of neovascularization of CAM induced by bFGF 60ng and treated with celecoxib $60 \mu \mathrm{g}$ (white arrow), none of capillary blood vessels moving into the disk implanted on CAM (black arrow); (C) capillary of neovascularization of CAM induced by bFGF $60 \mathrm{ng}$ and treated with EPMC $60 \mu \mathrm{g}$ (white arrow), none of capillary blood vessels moving into the disk implanted on CAM (black arrow)

The endothelial cell counts of CAM bFGFinduced capillaries in the negative control group were higher than in the EPMC-treated groups (Figure 2).

Treatment of CAM with EPMC caused lysis of the endothelial cells (Figure 3). The higher EPMC doses caused more endothelial cell lysis and decreased CAM neovascularization more strongly. EPMC as an antiangiogenic agent at doses of 30 and $60 \mu \mathrm{g}$ was less active compared to celecoxib $60 \mu \mathrm{g}$. There were a statistically significant differences in antiangiogenic potency between EPMC doses of 90 and $120 \mu \mathrm{g}$. There were also a significant differences between celecoxib $60 \mu \mathrm{g}$ and EPMC at doses 90 and $120 \mu \mathrm{g}(\mathrm{p}<0.05)$.

\section{DISCUSSION}

Angiogenesis plays an important role in delivering oxygen and nutrients essential for tumor progression and invasion of surrounding tissues and vessels. The development of a new vascular network consists of several steps which are controlled by various endogenous stimulators and inhibitors. ${ }^{(18)}$ Antiangiogenic therapy has great potential for developing new cancer treatment methods in the future. ${ }^{(19)}$
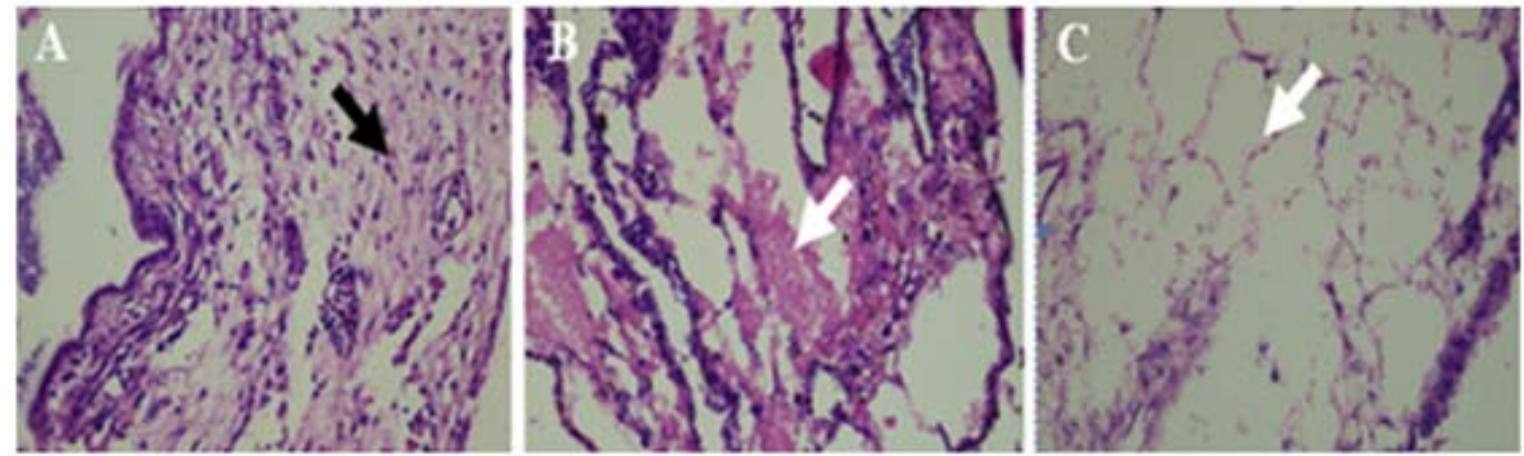

Figure 3. Photomicrograph images of endothelial cells of CAM using an inverted phase contrast microscope

(Nikon H600L; camera DS Fi2 300 megapixel) at 400 magnification. CAM induced by b bFGF (black arrow), the morphology of endothelial cells is good. (B) CAM induced by b FGF and treated by celecoxib 60 $\mu \mathrm{g}$. Some of the endothelial cells are lyzed (white arrow). (C) CAM induced by b FGF and treated by EPMC $60 \mu \mathrm{g}$. It also appears that some of the endothelial cells are lyzed (white arrow) 
He et al. ${ }^{(12)}$ found by semiquantitative reverse transcription polymerase chain reaction assay that EPMC influences multiple molecular targets connected to angiogenesis. A recent study, showed the chemopreventive effect of EPMC against fibrosarcoma in mice and EPMC's capability to interact with COX-2. ${ }^{(8)}$ The results of our molecular docking study on EPMC's interaction with the tyrosine kinase receptor (PDB 1XKK) predict the probable mechanism of EPMC as a cancer chemopreventive agent.

Molecular docking is a virtual method, in which the ligand is placed on the binding site in such a manner as to obtain the lowest potential energy. The docking process consists of testing the coordinate area of the target binding mode and scoring each possible ligand pose into that site. The lowest value of rerank scores is expected as the best binding mode. ${ }^{(15)}$ Our results are in line with those of previous studies and tyrosine kinase is one of the molecular targets of EPMC for inhibition of angiogenesis. Altun et al. ${ }^{(20)}$ reported that tyrosine kinase inhibitors are excellent agents for treating colorectal cancer and angiogenesis in a CAM model.

It is known that COX-2 may indirectly provoke angiogenesis by increasing the production of angiogenic factors, such as vascular endothelial growth factor (VEGF). ${ }^{(18,19)}$ Our study also supports the antiangiogenic activity of the COX-2 inhibitor celecoxib in the CAM assay. Several reports revealed that there is a significant association between COX-2 expression and VEGF-C expression. The combination of celecoxib with tamoxiven is a potential drug for treatment of breast cancers expressing high levels of VEGF. ${ }^{(18)}$ Celecoxib as COX-2 inhibitor has been reported to suppress angiogenesis and growth of secondary bone tumors. ${ }^{(19)}$ Celecoxib overturns the expression of VEGF by constraining the production of $\mathrm{PGE}_{2}$ and the stimulation of some signal transduction pathways by which the expression of VEGF is upregulated. ${ }^{(21)}$

Basic FGF as a proangiogenic agent causes chronic inflammation that markedly increases the risk for the development of cancer, and therefore angiogenesis and VEGF signaling might pose an important link between inflammation and tumor development. ${ }^{(19,20)}$ Histopathological analysis showed the presence of inflammatory cells on CAM induced by bFGF. Even though not directly proinflammatory, bFGF synergistically forces inflammatory mediator-induced leukocyte recruitment, thus indicating the relationship between inflammation and angiogenesis. ${ }^{(22,23)}$

Angiogenesis is triggered by increased arachidonic acid production as a result of prostaglandin $\mathrm{PGE}_{2}$ metabolism catalyzed by COX-2. Prostaglandin affects vascularization and the cancer metastatic process that encourages the expression of proangiogenic factors, such as VEGF and fibroblast growth factor (FGF). ${ }^{(24)} \mathrm{A}$ previous research study reported that EPMC blocked COX-2 expession in the T47D cell line and caused lysis of that cell line. ${ }^{(25)}$ This fact strengthens our prediction of the ability of antiinflammatory substances like EPMC to block the starting step of angiogenesis. Therefore, the present study was designed to investigate the potential angiogenesis inhibitory effect of EPMC on CAM. The outcomes showed that EPMC is a potent antiangiogenic substance, therefore it can be used as a cancer chemopreventive agent, in agreement with our earlier report. Although the antiangiogenic activity of EPMC is lower than that of celecoxib, EPMC can be used as lead compound for developing agents with higher antiangiogenic activities. EPMC can also be combined with other antiangiogenic drugs, e.g. bevacizumab, or with COX-2 inhibitors, such as celecoxib, so reducing the dose and decreasing the side effects of the drugs. ${ }^{(1,9)}$

One limitation of this study is the virtual experimental study of interactions between EPMC and tyrosine kinase, which eliminated the lipophilic effect of the compound. So, in our future research the experiment will be conducted by in vitro studies based on the present results. We will also study the inhibition of VEGF expression on CAM using EPMC. 
The clinical implication of this study is the availability of an easily obtainable natural compound as a cancer chemopreventive agent. Ethyl $p$-methoxycinnamate is easily obtained from Kaempferia galanga, therefore its use may lower the expected cost of cancer treatment and increase life expectancy.

\section{CONCLUSIONS}

Ethyl $p$-methoxycinnamate has antiangiogenic potency and its activity is dosedependent. The antiangiogenic potency of EPMC is associated with its inhibition of tyrosine kinase.

\section{ACKNOWLEDGMENT}

We thank the Ministry of National Education of the Republic of Indonesia, and the Rector of Airlangga University, Indonesia, for financial support in 2014. Thanks are also due to Prof. Dr. Siswandono, MS., Apt for MVD program support.

\section{REFERENCES}

1. Gotink KJ, Verheul HMW. Anti-angiogenic tyrosinee kinase inhibitors: what is their mechanism of action? Angiogenesis 2010;13:114.

2. Filho AL, Lopes JM, Schmitt FC. Angiogenesis and breast cancer. J Oncol 2010. doi: 10.1155/ 2010/576384.

3. Kyzas PA, Stefanou D, Agnantis NJ. COX-2 expression correlates with VEGF-C and lymph node metastases in patients with head and neck squamous cell carcinoma. Mod Pathol 2005;18: 153-60.

4. Athikomkulchai S, Vaymhasuwan P, Tunvichien $S$, et al. The development of sunscreen product from Kaempferia galanga. J Health Res 2007;21:253-6.

5. Kusumawati I, Yusuf H. Phospholipid complex as a carrier of Kaempferia galanga rhizoma extract to improve its analgesic activity. IJPPS 2011;3 Suppl 1:S44-6.

6. Umar MI, Asnawi MZ, Sadikun A, et al. Ethyl p-methoxycinnamate isolated from Kaempferia galanga inhibits inflammation by suppressing interleukin-1, tumor necrosis factor-?and angiogenesis by blocking endothelial functions. Clinics 2014;69:134-44.

7. Aroonrerk N, Kamkaen N. Anti-inflammatory activity of Quercus Infectoria, Glycyrrhiza Uralensis, Kaempferia galanga and Coptis Chinensis: the main components of Thai herbal remedies for aphthous ulcer. J Health Res 2009; 23:17-22.

8. Ekowati J, Bimo AT, Sukardiman, et al. Structure modification of ethyl $p$-methoxycinnamate and their bioassay as chemopreventive agent against mice's fibrosarcoma. IJPPS 2012;4 Suppl 3:S 528-32.

9. Greehough A, Smart HJM, Moore AE, et al. The COX-2/PGE 2 pathway: key roles in the hallmarks of cancer and adaptation to the tumour microenvironment. Carcinog 2009;30:377-86.

10. Yao L, Liu F, Hong L, et al. The function and mechanism of COX-2 in angiogenesis of gastric cancer cells. J Exp Clin Cancer Res 2011;30:13. doi:10.1186/1756-9966-30-13.

11. Roskoski R. Sunitinib: a VEGF and PDGF receptor protein kinase and angiogenesis inhibitor. Biochem Biophys Res Commun 2007; 356:323-8.

12. He ZH, Yue GG, Lau CB, et al. Antiangiogenic effects and mechanisms of trans-ethyl $p$ methoxycinnamate from Kaempferia galanga $\mathrm{L}$. J Agric Food Chem 2012;60:11309-17.

13. Ribatti D. The chick embryo chorioallantoic membrane as in vivo assay to study antiangiogenesis. Pharm 2010;3:482-513.

14. Lokman NA, Elder ASF, Ricciardelli C, Oehler MK. Chick chorioallantoic membrane (CAM) assay as an in vivo model to study the effect of newly identified molecules on ovarian cancer invasion and metastasis. Intern J Molec Sci 2012;13:9959-70. doi: 10.3390/ijms13089959.

15. Kusumaningrum S, Budianto E, Kosela S, et al. The molecular docking of 1,4-naphthoquinone derivatives as inhibitors of polo-like kinase 1 using Molegro Virtual Docker. J App Sci 2014;4: 47-53.

16. Diyah NW, Ekowati J, Siswandono. Synthesis and anti tumor activity evaluation of $N, N^{\prime}$ dibenzoyl- $N, N$ '-diethylurea against human breast cancer cell line (MCF-7). IJPPS 2014;6: 315-8.

17. Salamah N, Sugiyanto, Hartati MS, et al. Isolasi dan identifikasi eurycomanone akar pasak bumi (Eurycoma longifolia, Jack) serta uji anti angiogenik. Majalah Farmasi Indonesia 2009; 20:118-26.

18. Kumar BNP, Rajput S, Dey KK, et al. Celecoxib alleviates tamoxifen-instigated angiogenic effect 
by ROS-dependent VEGF/VEGFR2 autocrine signaling. BMC Cancer 2013;13:273. doi: 10. 1186/1471-2407-13-273.

19. Klenke FM, Gebhard M, Ewerbeck V, et al. The selective COX-2 inhibitor Celecoxib suppresses angiogenesis and growth of secondary bone tumors: an intravital microscopy study in mice. BMC Cancer 2006;6:9. doi:10.1186/1471-24076-9.

20. Altun A, Temiz TK, Balci E, et al. Effects of tyrosine kinase inhibitor E7080 and eNOS inhibitor L-NIO on colorectal cancer alone and in combination. Chin J Cancer Res 2013;25:57284.

21. Wang L, Chen W, Xie X, et al. Celecoxib inhibits tumor growth and angiogenesis in an othotopic implantation tumor model of human cancer. Exp Oncol 2008;30:42-51.
22. Fox SB, Generally DG, Harris AL. Review breast tumor angiogenesis. Breast Cancer Res 2007;9: $1-11$.

23. Zittermann SI, Issekutz AC. Basic fibroblast growth factor (bFGF, FGF-2) potentiates leukocyte recruitment to inflammation by enhancing endothelial adhesion molecule expression. Am J Patol 2006;168:835-46.

24. Sahin E. Cyclooxygenase-1 in cancer and angiogenesis. Angiology 2009;60:242-53.

25. Ekowati J, Tejo BA, Susilo I, et al. Microwave assisted synthesis of ethyl $p$-methoxycinnamate derivative and its activity to blockade COX-2 expression on breast cancer cell line. Proceeding of the $3^{\text {rd }}$ ICPAPS; 2013 June 18-19. Yogyakarta. p.32-8. 